\title{
Kemampuan Keluarga dalam Merawat Orang dengan Gangguan Jiwa
}

\author{
Sulastri \\ Jurusan Keperawatan, Politeknik Kesehatan Tanjungkarang, Indonesia \\ Email: sulas_harris@yahoo.co.id
}

\begin{abstract}
Family Ability in Caring for People with Mental Disorders. The dependence level of the patient on the family to fulfill their basic needs was quite high. This was certainly going to interfere with the exercise of family members duties, functions, and responsibilities. This will be disturbed the achievement of the family goals when the family was viewed as a system. This can happen because patients who experience mental disorders were considered as a family burden that can affect the system in the family as a whole. Skills were needed for a family to care patient/person with a mental disorder (ODGJ). Ability to care is a measure of the quality of life ODGJ. This study was to analyze the family ability in caring for patients with mental disorder. This was using a qualitative approach, cross-sectional design. The population was families who have family members with a mental disorder in the work area of Sragi Psychiatric Clinic, South Lampung. Sampling method in this research was purposive sampling and obtained samples of as many as 40 people. Data were taken using questionnaires sheet capabilities of families and were analyzed frequency distribution to measure the ability of the family in caring for psychiatric patients. The analytical test showed that most of the family's ability on the group inadequate. The psychiatric clinic should develop a community mental health nursing programs and make health education or family psychoeducation, as one intervention for families to improve their knowledge and skills in psychiatric treating patients.
\end{abstract}

Keywords: Family ability, Psychiatric

\begin{abstract}
Abstrak: Kemampuan Keluarga dalam Merawat Orang dengan Gangguan Jiwa. Tingkat ketergantungan pasien terhadap pemenuhan kebutuhan dasarnya pada keluarga cukup tinggi. Hal ini tentunya akan mengganggu pelaksanaan tugas dan tanggung jawab anggota keluarga dalam menjalankan fungsinya masing-masing. Apabila keluarga dipandang sebagai suatu sistem, maka akan terganggulah pencapaian tujuan keluarga. Hal ini bisa terjadi karena pasien yang mengalami gangguan jiwa tersebut dianggap sebagai beban keluarga yang dapat mempengaruhi sistem dalam keluarga secara keseluruhan. Perlu keterampilan agar keluarga mampu merawat pasien/orang dengan gangguan jiwa (ODGJ). Kemampuan melakukan perawatan merupakan tolak ukur kualitas hidup ODGJ. Tujuan penelitian ini adalah untuk menganalisis kemampuan keluarga dalam merawat ODGJ. Penelitian ini adalah penelitian kuantitatif, dengan rancangan cross sectional. Populasi dalam penelitian ini adalahh keluarga yang memiliki anggota keluarga ODGJ di wilayah puskesmas Sragi Lampung Selatan. Metode pengambilan sampel dalam penelitian ini adalah dengan cara purposive sampling dan didapatkan sampel sebanyak 40 orang. Pengambilan data menggunakan lembar kuesioner kemampuan keluarga. Pada analisis dilakukan menggunakan distribusi frekuensi untuk mengukur kemampuan keluarga dalam merawat ODGJ. Hasil uji statistik diketahui sebagian besar kemampuan keluarga pada kelompok kurang memadai. Disarankan pada puskesmas untuk mengembangan program keperawatan kesehatan jiwa komunitas dan menjadikan pendidikan kesehatan atau psikoedukasi keluarga sebagai salah satu intervensi bagi keluarga untuk meningkatkan pengetahuan dan kemampuan dalam merawat ODGJ.
\end{abstract}

Kata kunci: Kemampuan keluarga, Gangguan jiwa

Kesehatan jiwa merupakan sesuatu yang penting dalam kehidupan manusia. Kesehatan jiwa menjadi satu kesatuan yang tak dapat dipisahkan dengan kesehatan secara fisik. Menurut Mohr (2006) kesehatan jiwa adalah suatu penampilan fungsi mental yang sukses, yang ditunjukkan dengan aktivitas yang produktif, hubungan yang berarti dan kemampuan beradaptasi terhadap perubahan serta koping yang efektif. Kesehatan jiwa merujuk pada kemampuan untuk mengatasi masalah, saling melengkapi dalam pekerjaan dan kasih sayang, mampu bertahan dalam krisis tanpa bantuan orang lain dan mempertahankan persepsi sehat dengan menikmati hidupnya, punya tujuan dan batasan secara realistik serta mampu 
menempatkan diri secara tepat (mandiri, bergantung maupun saling ketergantungan). Keluarga berperan penting dalam merawat pasien. Kurang perhatian dari keluarga menyebabkan pasien menjadi gelandangan psikoitik.

Menurut Hawari (dalam Wiyati, R. dkk 2010), salah satu kendala dalam upaya penyembuhan pasien gangguan jiwa adalah pengetahuan masyarakat dan keluarga. Keluarga dan masyarakat menganggap gangguan jiwa adalah penyakit yang memalukan dan membawa aib bagi keluarga. Kondisi ini diperberat dengan sikap keluarga yang cenderung mengisolasi, mengucilkan bahkan memasung pasien.

Tingkat ketergantungan pasien terhadap pemenuhan kebutuhan dasarnya pada keluarga cukup tinggi. Hal ini tentunya akan mengganggu pelaksanaan tugas dan tanggung jawab anggota keluarga dalam menjalankan fungsinya masingmasing. Apabila keluarga dipandang sebagai suatu sistem, maka akan terganggulah pencapaian tujuan keluarga. Hal ini bisa terjadi karena pasien yang mengalami gangguan jiwa tersebut dianggap sebagai beban keluarga yang dapat mempengaruhi sistem dalam keluarga secara keseluruhan.

Pemahaman sebagian keluarga yang masih belum tepat tentang perawatan ODGJ mengakibatkan sikap yang negatif terhadap pasien. Sikap negatif keluarga terhadap pasien dapat dilihat dari anggapan bahwa penyakit yang dialami pasien adalah penyakit menetap dan tidak dapat disembuhkan sehingga keluarga cenderung membiarkan pasien asal tidak mengganggu. Keluarga mengganggap halusinasi yang dialami pasien adalah hal yang wajar karena pasien adalah penderita gangguan jiwa. Hampir semua keluarga menganggap bahwa pasien hanya menjadi beban keluarga karena ketidakmampuan dalam merawat diri sendiri (Marfuah, D; Noviyanti, RD, 2017).

Berdasarkan pra survei dilakukkan pada bulan Agustus 2017 angka kunjungan pasien gangguan jiwa dan gangguan mental emosional di Puskesmas Sragi relatif sedikit. Kondisi berbanding terbalik dengan hasil kunjungan dan deteksi yang dilakukan di wilayah kerja Puskesmas Sragi, ditemukan 45 kasus gangguan jiwa, 3 diantaranya dirawat dengan kondisi terpasung. Pemasungan yang dilakukan dengan menggunakan rantai yang diikatkan pada tiang rumah pada dua pasien dan satu orang pasien dipasung menggunakan balok kayu (pohon). Berdasarkan fenomena ini peneliti ingin mengetahui bagaimana kemampuan keluarga dalam perawatan pasien. Sebagian pasien yang dikunjungi tampak kurang perawatan diri. Hasil wawancara kepada 10 keluarga pasien gangguan jiwa terdapat $90 \%$ keluarga mengatakan terbebani dalam hal biaya pengobatan pasien, waktu untuk merawat, malu memiliki anggota keluarga gangguan jiwa, tergangu dalam bekerja, sehingga berkurangnya produktivitas untuk mencari nafkah.

Penelitian ini bertujuan mengidentifikasi kemampuan keluarga dalam merawat anggota keluarganya. Berdasarkan data yang diperoleh diharapkan dapat bermanfaat sebagai data dasar untuk penelitian lebih lanjut untuk pemberian intervensi untuk penyelesaian masalah baik dalam bentuk program kegiatan dan penelitian lebih lanjut.

\section{METODE}

Penelitian ini menggunakan jenis penelitian kuantitatif dengan desain cross sectional dengan responden keluarga yang memiliki anggota keluarga gangguan jiwa di wilayah kerja puskesmas Sragi Lampung Selatan. Penelitian ini dilakukan untuk mengetahui kemampuan keluarga dalam merawat pasien gangguan jiwa (ODGJ).

Alat pengumpulan data pada penelitian ini menggunakan dua Instrumen/kuesioner. Kuesioner yang pertama yang digunakan untuk memperoleh data demografi responden, usia, jenis kelamin, pendidikan, dan lama pasien sakit. Kuesioner ini dibuat oleh peneliti dengan menggunakan pertanyaan terbuka. Kuesioner yang kedua Instrumen untuk memperoleh data tentang kemampuan keluarga berdasarkan lima tugas keluarga alam kesehatan, yaitu mengenal masalah kesehatan 4 pernyataan (1-4), membuat keputusan untuk merawat 3 pernyataan (5-7), memberikan perawatan 9 pernyataan (8-16), memodifikasi lingkungan 3 pernyataan (17-19), dan memanfaatkan pelayanan kesehatan 5 pernyataan (20-24) (Friedman, Marilyn M. (2010)). Kuesioner ini terdiri atas 24 pernyataan yang diisi dengan skala $1=$ tidak, $2=$ ya untuk pernyataan positif dan skala $1=y a, 2=$ tidak untuk pernyataan negatif.

Penelitian ini telah dilaksanakan di wilayah kerja puskesmas Sragi Lampung Selatan. Pemilihan tempat ditentukan karena ditemukan kasus gangguan jiwa. Pasien yang dirawat jalan dan tinggal bersama keluarganya, akan lebih mudah untuk menilai kemampuan keluarganya. Hal ini disebabkan karena keluarga selama 24 jam setiap hari berinteraksi dengan pasien dalam melaksanakan tugas kesehatan keluarga. 
Penelitian dilakukan pada keluarga yang memiliki anggota keluarga gangguan jiwa atau ODGJ sebanyak 40 orang dari 45 keluarga dengan anggota keluarga ODGJ. Pemilihan keluarga dilakukan berdasarkan keberadaan saat pengumpukan data dilakukan dan bersedia untuk menjadi responden penelitian. Pengumpulan data dilakukan dengan melakukan menggunakan kuesioner yang sudah disiapkan oleh peneliti. Analisis dilakukan dalam secara univariat dan bivariat.

HASIL

\section{Karakteristik Umur dan Lama Sakit}

Tabel 1. Analisis Karakteristik Keluarga berdasarkan Umur dan Lama Sakit

\begin{tabular}{lccccc}
\hline \multicolumn{1}{c}{ Variabel } & $\mathbf{n}$ & Mean & Med & SD & Min-Maks \\
\hline Umur & 40 & 44,35 & 44,57 & 10,03 & $30-62$ \\
\hline $\begin{array}{l}\text { Lama anggota } \\
\text { keluarga sakit }\end{array}$ & 40 & 7,25 & 6,5 & 3,74 & $1-15$ \\
\hline
\end{tabular}

Hasil analisis data diketahui rata-rata usia 44 tahun. Hal ini menunjukkan tanggungjawab merawat pasien gangguan jiwa dalam keluarga diberikan oleh anggota keluarga yang berusia produktif.

Lama anggota (pasien) sakit diketahui ratarata lama sakit 7 tahun. Hasil ini menunjukkan pasien yang dirawat adalah pasien dengan kondisi yang sudah kronis.

\section{Karakteristik Jenis Kelamin, Pendidikan dan Pekerjaaan}

Tabel 2. Analisis Karakteristik Keluarga Jenis Kelamin, Pendidikan dan Pekerjaaan Responden

\begin{tabular}{lcc}
\hline \multirow{2}{*}{ Kategori } & \multicolumn{2}{c}{ Intervensi } \\
\cline { 2 - 3 } & Jlh & \% \\
\hline Jenis Kelamin & & \\
Perempuan & 17 & 42,5 \\
Laki-Laki & 23 & 57,5 \\
\hline Pendidikan & & \\
Tinggi & 1 & 2,5 \\
Menengah & 17 & 42,5 \\
Dasar & 22 & 55 \\
\hline Pekerjaan & & \\
Bekerja & 24 & 60 \\
Ibu Rumah Tangga & 16 & 40 \\
\hline
\end{tabular}

Berdasarkan hasil analisis pada tabel 2 . sebagian besar responden yang datang adalah laki-laki, dengan pendidikan terbanyak yaitu pendidikan dasar (SD dan SMP), dan sebagian besar responden bekerja. Hasil ini menunjukkan bahwa yang menjadi responden sebaian besar adalah kepala keluarga. Tidak dapat dipungkiri kepala keluarga merupakan penanggungjawab pada anak-anak dan keluarganya. Hal ini menunjukkan bahwa tanggungjwab merawat umumnya diberikan oleh kepala keluarga. Hasil analisis pendidikan menunjukkan sebagian besar responden berpendidikan dasar, sementara untuk pekerjaan sebagian besar bekerja.

\section{Rerata Kemampuan Keluarga}

Tabel 3. Rerata Kemampuan Keluarga Merawat Pasien Gangguan Jiwa

\begin{tabular}{ccccc}
\hline Rerata & Mean & SD & Min & Maks \\
\cline { 2 - 5 } $\begin{array}{c}\text { Kemampuan } \\
\text { keluarga }\end{array}$ & 32,6 & 6,34 & 24 & 46 \\
\hline
\end{tabular}

Dari tabel 3 dapat dilihat bahwa rerata kemampuan keluarga 32,6 dengan nilai minimum 24 dan maksimum 46, dan standar deviasi 6,34. Rerata menunjukkan kemampuan merawat pada rentang mampu.

\section{Kemampuan Keluarga}

Tabel 4. Distribusi Frekuensi Kemampuan Keluarga merawat pasien Gangguan Jiwa

\begin{tabular}{lcc}
\hline \multicolumn{1}{c}{ Kemampuan } & Jumlah & \% \\
\hline Memadai & 17 & 42,5 \\
\hline Kurang Memadai & 23 & 57,5 \\
\hline Total & 40 & 100 \\
\hline
\end{tabular}

Dari tabel 4 dapat dilihat bahwa sebagian besar kemampuan keluarga kurang memadai.

\section{PEMBAHASAN}

Dari hasil penelitian diperoleh bahwa kemampuan merawat pasien gangguan jiwa relatif rendah atau kurang memadai. Menurut Lestari, (2011) bahwa prinsip belajar merupakan proses yang dilakukan seumur hidup, manusia memiliki kemampuan untuk belajar sejak lahir sampai akhir hayat. Pemberian edukasi memberikan informasi pada keluarga tentang cara perawatan pasien gangguan jiwa. Melalui aktivitas ini terjadi proses pembelajaran yangg dilakukan oleh keluarga dengan menyerap informasi yang diberikan dan mengaplikasikan langsung pada anggota keluarganya. Berdasarkan survey pada warga dan wawancara pada petugas kesehatan di puskesmas Sragi bahwa informasi yang diperoleh masyarakat relatif minim. Keterbatasan sumber daya manusia yang memiliki pengalaman dan kemampuan khusus 
tentang kesehatan dan keperawatan jiwa sangat terbatas. Sebagian petugas yang sudah mengikuti pelatihan pindah tugas tanpa adanya transfer pengetahuan pada pemegang program yang ada. Selain itu saat ini program kesehatan jiwa berada pada program penyakit tidak menular.

Pengetahuan keluarga pasien dapat digambarkan bahwa pada dasarnya keluarga memahami tentang pentingnya perawatan pada ODGJ. Pengetahuan yang dimiliki keluarga masih terbatas pasien perlu berobat agar tidak kambuh. Sebagian keluarga tidak memperhatikan apakah obat diminum pasien atau tidak. Keluarga juga tidak memahami bahwa keteraturan minum obat menentukan kondisi pasien. Keluarga menganggap apabila gejala berkurang berarti pasien sudah sembuh sehingga tidak perlu diberikan obat lagi. Keluarga masih belum memahami tentang cara mengontrol halusinasi. Keluarga juga beranggapan bahwa apabila pasien tidak membahayakan maka tidak perlu dikhawatirkan.

Pemahaman sebagian keluarga yang masih belum tepat tentang perawatan pasien skizofrenia dengan halusinasi mengakibatkan sikap yang negatif terhadap pasien. Sikap negatif keluarga terhadap pasien dapat dilihat dari anggapan bahwa penyakit yang dialami pasien adalah penyakit menetap dan tidak dapat disembuhkan sehingga keluarga cenderung membiarkan pasien asal tidak mengganggu.

Keluarga mengganggap halusinasi yang dialami pasien adalah hal yang wajar karena pasien adalah penderita gangguan jiwa. Hampir semua keluarga menganggap bahwa pasien hanya menjadi beban keluarga karena ketidakmampuan dalam merawat diri sendiri. Sikap negatif keluarga terhadap pasien juga terlihat dari persepsi keluarga bahwa perubahan perilaku yang ditunjukkan pasien sebagai bentuk gangguan jin atau makhluk halus. Sehingga keluarga meyakini bahwa pengobatan perlu dilakukan apabila timbul perilaku yang tidak wajar terjadi pada pasien, akan tetapi pilihan pertama yang dilakukan adalah pengobatan ke paranormal. Peneliti juga menemukan sebagian keluarga yang merasa bahwa gangguan jiwa sebagai aib, sehinnga keluarga enggan menceritakan permasalahan yang timbul dalam merawat pasien kepada anggota keluarga lain maupun dengan orang lain. Sikap keluarga yang demikian dapat memicu kekambuhan pasien karena dapat memperburuk kondisi pasien. Sikap negatif keluarga terhadap pasien, berakibat timbulnya perilaku merawat yang tidak tepat. Peneliti mendapatkan keluarga yang menghentikan pengobatan tanpa persetujuan dokter, keluarga yang tidak mengajak pasien berkomunikasi dan membatasi aktivitas pasien dalam pergaulan (Marfuah, D., Noviyanti, RD., 2017).

Menurut Stuat \& Laraia, (2015), intervensi perlu diberikan pada keluarga, salah satunya melalui psikoedukasi keluarga. Psikoedukasi keluarga adalah salah satu elemen program perawatan kesehatan jiwa keluarga dengan cara pemberian informasi dan edukasi melalui komunikasi terapeutik. Program Psikoedukasi merupakan pendekatan bersifat edukasi dan pragmatik.Tujuan utama psikoedukasi keluarga adalah untuk berbagi informasi tentang perawatan kesehatan jiwa. Terapi ini dapat diberikan juga pada keluarga yang memuliki anggota dengan gangguan jiwa yang ingin mempertahankan kesehatan jiwanya atau meningkatkan derajat kesehatan jiwa.

Dari hasil penelitian menunjukkan masih rendahkan kemampun keluarga, bahkan pada beberapa kasus masih ditemukan ODGJ yang dipasung. Menurut Broch, (2001); Minas \& Diatri, (2008) dalam Indra (2017), di beberapa daerah di Indonesia, pasung masih digunakan sebagai alat untuk menangani klien gangguan jiwa di rumah. Saat ini, masih banyak klien gangguan jiwa yang didiskriminasikan haknya baik oleh keluarga maupun masyarakat sekitar melalui pemasungan. Sosialisasi kepada masyarakat terkait dengan larangan "tradisi" memasung klien gangguan jiwa berat yang kerap dilakukan penduduk yang berdomisili di pedesaan dan pedalaman terus berupaya dilakukan antara lain dengan memberdayakan petugas kesehatan di tengah-tengah masyarakat. Di Indonesia, kata pasung mengacu kepada pengekangan fisik atau pengurungan terhadap pelaku kejahatan, orang-orang dengan gangguan jiwa danyang melakukan tindak kekerasan yang dianggap berbahaya.

Keluarga merupakan unit yang paling dekat dengan klien dan merupakan perawatan utama bagi klien ganggun jiwa. Keluarga berperan dalam menentukan cara atau asuhan yang diperlukan di rumah. Rendahnya peran keluarga juga dipicu oleh rendahnya motivasi dari keluarga sebagai tenaga penggerak. Motivasi merupakan faktor penting yang mempengaruhi perilaku manusia karena dengan adanya motivasimaka manusia akan berusaha semampunya untuk mencapai tujuan. Motivasi keluarga dapat ditingkatkan dengan pemberian asuhan keperawatan yang berfokus pada keluarga bukan hanya memulihkan keadaan klien. Keluarga merupakan faktor penting yang menentukan keberhasilan asuhan keperawatan pada pasien gangguan jiwa. Keluarga yang 
mendukung pasien secara konsisten akan membuat pasien mampu mempertahankan program pengobatan secara optimal, (Yosep, 2008; Keliat,2008; Setiadi, 2008, dalam Amelia 2015).

Diperlukan minat yang tinggi pada keluarga untuk dapat merawat anggota keluarga yang mengalami gangguan jiwa secara optimal. Minat dipengaruhi oleh beberapa hal, antara lain: umur, pengetahuan, dan tingkat pendidikan. Responden pada penelitian ini berada pada rentang usia produktif. Pada kelompok ini produktivitas untuk menapkahi keluarga menjadi tanggung jawab responden. Umur berkaitan dengan lama individu hidup, semakain cukup umurnya semaikin banyak pengalamannya. Namun demikian tanggungjawab mencari nafkah tidak memungkinkan individu untuk berada dirumah, kondisi ini tentu saja berpengaruh terhadap waktu dan perawatan untuk pasien. Responden yang mempunyai kemampuan dalam merawat ODGJ adalah responden yang berusia produktif. Responden yangsudah dewasa akan lebihmatang dalam melakukan segala bentukpekerjaan, terutama dalam hal merawat ODGJ. Semakin dewasa usia responden menyebabkan responden banyak mendapatkan informasi dan pengalamantentang cara merawat pasien gangguan jiwa sehingga menyebabkan responden mempunyai motivasi yang cukup baik.

Pengetahuan merupakan faktor penting yang menunjang kemampuan seseorang. Minimnya informasi yang diperoleh keluarga tentang perawatan pasien tentu memberikan dampak yang negatif terhadap kualitas perawatan. Semakin cukup tingkat pengetahuan dan kekuatan seseorang akan lebih matang dalam berpikir dan menerima informasi dari segi kepercayaan masyarakat, seseorang yang lebih dewasa akan lebih dipercaya dari orang yang belum cukup tinggi kedewasaanya. Hal ini sebagai akibat dari pengalaman dan kematangan jiwanya (Wawan, 2010 dalam Amelia, 2015). Kemampuan keluarga juga dipengaruhi oleh tingkat pendidikan. Hasil penelitian menunjukkan dari 40 responden $55 \%$ berpendidikan dasar (SDSMP). Notoatmodjo (2010) menyatakan bahwa pendidikan merupakan proses pembinaan tingkah laku sehingga di dalam masyarakat pendidikan harus membimbing ke arah suatu kepercayaan yang memberikan dorongan motivasi yang sesuai dengan kecakapan yang diperlukan serta kesempatan untuk berlatih. Pendidikan mempunyai tiga aspek yaitu pembentukan kepribadian, pengembangan ilmu pengetahuan dan penerapan ilmu pengetahuan. Seharusnya pengetahuan keluarga dapat ditingkatkan melalui pemberian informasi yang memadai. Banyak momen yang memungkinkan keluarga bias berinteraksi dengan petugas kesehata, seperti saat control ulang, mengambil obat, bahkan ODGJ yang pernah menjalani perawatan. Menurut Notoatmojo (2010) informasi yang diperoleh baik dari pendidikan formal maupun non formal dapat memberikan pengaruh jangka pendek sehingga menghasilkan perubahan atau peningkatan pengetahuan. Pendidikan non formal tersebut dapat mempengaruhi pengetahuan keluarga tentang cara merawat pasien menjadi tinggi. Dapat disimpulkan bahwa jika pengetahuan keluarga tinggi maka akan meningkatkan kemampuan keluarga dalam memberikan perawatan pada pasien yang hasilnya pun akan menjadi optimal.

Menurut Stuart dan Sundeen (2015), informasi pada keluarga merupakan salah satu faktor penting. Pendidikan kesehatan merupakan strategi dalam perawatan kesehatan jiwa pada keluarga dengan cara pemberian informasi dan edukasi melalui komunikasi yang terapeutik. Pendidikan kesehatan merupakan pendekatan yang bersifat edukasi dan pragmatis. Melalui pendidikan kesehatan memungkinkan keluarga saling bertukar informasi tentang perawatan kesehatan mental dan pengobatan yang dibutuhkan untuk menurunkan gejala dan lainnya. Menurut Widati, R (2010) keluarga yang mendapatkan informasi yang memadai menunjukkan kemampuan yang lebih baik dalam perawatan anggota keluarga, disamping kecemasan yang dialami oleh keluarga juga mengalai penurunan, sebagai dampak dari terpenuhinya informasi yang ingin diperoleh oleh keluarga untuk merawat anggota keluarganya yang sakit.

Peningkatan kemampuan merawat pasien gangguan jiwa dapat diperoleh melalui intervensi untuk meningkatkan pengetahuan keluarga, kekhawatiran yang muncul karena ketidaktahuan dapat teratasi. Berdasarkan kondisi ini peneliti berpendapat bahwa dengan hanya mendapatkan pelayanan medis dan penjelasan yang diperoleh saat melakukan kontrol ke pelayanan kesehatan tidak memberikan pengetahuan yang memadai. Hasil ini dimungkinkan waktu yang relatif singkat saat kunjungan, dan informasi yang diberikan hanya berfokus pada informasi medis dan pengobatan, sementara informasi tentang cara perawatan dan diagnosis keperawatan sangat terbatas, itu pun jika keluarga pro aktif untuk bertanya. Sebagian petugas boleh jadi memberikan informasi yang memadai, tetapi komunikasi umumnya berjalan satu arah, tidak ada kedektan yang terjadil antara terapi dengan 
pasien. Sebagaimana yang disampaikan oleh Nurhidayah (2010, dalam Lestari, 2011), menyatakan bahwa pendidikan kesehatan sangat dipengaruhi oleh motivasi keluarga (individu yang mendapatkan pendidikan kesehatan) untuk berubah.

Hasil penelitian Suryaningrum dan Wardani (2013), diketahui beban keluarga merawat pasien gangguan jiwa cukup tinggi pada yang kategori berat. Nuraenah, Mustikasari, \& Putri (2012) mendukung penelitian ini bahwa beban keluarga dalam merawat anggota keluarga yang mengalami gangguan jiwa yaitu $95 \%$. Beratnya beban yang dialami keluarga bisa dipengaruhi oleh berbagai ha salah satunya ekonomil. Hasil ini sesuai dengan penelitian Gururaj, Bada, Reddy dan Chandrashkar (2008 dalam Suryaningrum dan Wardani, 2013) menemukan bahwa dari enam dimensi beban keluarga dengan skizofrenia, skor finansial memiliki rata-rata yang paling tinggi. Oleh karena itu apabila keluarga tidak memiliki sumber dana yang cukup atau jaminan kesehatan, maka akan menjadi beban yang sangat berat bagi keluarga.

Sesuai hasil analisis kemampuan keluarga dalam perawatan ODGJ masih kurang memadai, pasien dalam merawat pasien gangguan jiwa. Hal ini diketahui dari adanya peningkatan nilai kemampuan pasien pada kelompok perlakuan yang cukup signifikan. Dampak positif berupa adanya peningkatan kemampuan pasien menjadi lebih tinggi diketahui dari nilai rata-rata yang meningkat. Hal ini disebabkan, pasien yang telah mendapat terapi psikoedukasi keluarga mempunyai tingkat kesiapan yang lebih baik dalam menghadapi pasien gangguan jiwa.

\section{DAFTAR PUSTAKA}

Amelia, RH. 2015. Motivasi Keluarga Dalam Merawat Anggota Keluarga Yang Mengalami Gangguan Jiwa Di Wilayah Kerja Puskesmas Urang Agung Sidoarjo. [Karya Tulis Ilmiah]. Mojokerto: D3 Keperawatan Politeknik Kesehatan Majapahit.

Friedman, Marilyn M. 2010. Buku Ajar Keperawatan Keluarga: Riset, Teori dan Praktek. Jakarta: EGC.

Indra. 2017. Pemasungan Penderita Gangguan Jiwa. www.penaindra.com

Lestari, A. 2011. Pengaruh Terapi Psikoedukasi terhadap Pengetahuan dan Tingkat Kecemasan Keluarga dalam Merawat Anggota Keluarga yang Mengalami
Pemberian stimulus dalam terapi psikoedukasi keluarga dapat meningkatkan bekal kemampuan keluarga dalam melakukan tindakan positif jika dengan mmberikan dukungan yang positif pd pasien. Jadi, dapat disimpulkan bahwa ada pengaruh terapi psikoedukasi keluarga terhadap kemampuan merawat pasien gangguan jiwa di Wilayah kerja Puskesmas Sragi Lampung Selatan Tahun 2017.

\section{SIMPULAN}

Berdasarkan data yang diperoleh pada penelitian ini dapat disimpulkan bahwa Kemampuan keluarga merawat pasien gangguan jiwa masih relatif rendah. Sebagian besar responden adalah kepala keluarga yang bertugas mencari nafkah, tingkat pendidikan sebagian besar adalah pendidikan Sekolah dasar dan Sekolah Menengah Pertama (pendidikan dasar).

\section{SARAN}

Melakukan pengabdian kepada masyarakat berdasarkan hasil penelitian. Perlu diberikan pendidikan kesehatan tentang kesehatan jiwa dan perawatan pasien gangguan jiwa. Membuat kerja sama Poltekkes Tanjungkarang dengan pihak puskesmas dan Desa/Kecamatan untuk menjadikan lokasi penelitian sebagai daerah binaan, khususnya untuk masalah kesehatan jiwa. Mengadakan kerjasama dengan organisasi keperawatan, seperti ikatan perawat kesehatan jiwa (IPKJI) untuk penerapan keperawatan kesehatan jiwa komunitas.
Tuberkulosis Paru di Kota Bandar Lampung. [Tesis]. Fakultas Ilmu Keperawatan, Universitas Indonesia.

Marfuah, D., Noviyanti, RD. 2017. Kemampuan Keluarga Merawat Pasien Skizofrenia Dengan Gejala Halusinasi. The 6th University Research Colloquium 2017, Universitas Muhammadiyah Magelang.

Notoatmodjo,S. 2010. Ilmu Perilaku Kesehatan. Jakarta: PT Rineka Cipta.

Nuraenah, Mustikasari, Putri. Y.S.E. 2012. Hubungan Dukungan Keluarga dan Beban Keluarga dalam Merawat Anggota dengan Riwayat Perilaku Kekerasan di RS Jiwa Islam Klender Jakarta Timur. Jurnal 
Keperawatan Jiwa. Volume 2, No. 1, Mei 2014; 41-50.

Stuart \& Laraia. 2015. Principles \& Practice of Psychiatric Nursing.7th Edition. St. Louise: Mosby.

Suryaningrum, S, Wardani, IY. 2013. Hubungan Antara Beban Keluarga Dengan Kemampuan Keluarga Merawat Pasien
Perilaku Kekerasan Di Poliklinik Rumah Sakit Marzoeki Mahdi Bogor. Jurnal Keperawatan Jiwa. Volume 1, No. 2, November 2013; 148-155148.

Wiyati, R. 2010. Pengaruh Psikoedukasi keluarga terhadapKemampuan Keluarga Merawat Pasien Isolasi Sosial. Jurnal Keperaatan Soedirman, Volume 5, No 2 Juli 2010. 